\title{
CULTURAL AND HISTORICAL EVOLUTION OF THE TURKISH LANGUAGE UNDER THE INFLUENCE AND BORROWING OF EUROPEAN LANGUAGES
}

\author{
(C) Yulia A. Petrova, Ksenia A. Kuleshova
}

\author{
Rostov State University of Economics, Rostov-on-Don, Russian Federation \\ science-almanac@mail.ru
}

The issue that is relevant for Turkish linguistics i.e. borrowing words from various European languages is considered, Turkish is a language belonging to the Turkic group of languages. For a long time, the Turkish alphabet consisted of letters in Arabic letters, until they were replaced by Latin ones. Currently, the national Turkish language is a synthesis of the Turkish folk language, Old Turkic language and Asian Turkic languages. The Turkish language also contains many borrowings that come from the vocabulary of other countries. It is noted that a large number of borrowings in it are from the French language, which penetrated into the vocabulary of the Turks through the inclusion of French literature in the educational program of schools. Since that time, an important criterion for human education was the ability to speak a foreign language. The growing importance of Turkey in the field of trade and shipping has led to the emergence of many marine terms borrowed from the Italian language. The Lausanne Treaty, on the basis of which there was an exchange of settlements between Turkey and Greece, is the reason for the Greek borrowings of feudal terminology and household vocabulary existing in the Turkish vocabulary. It is emphasized that the source of English borrowing is scientific and technological progress, the terminological explosion of which forced to adopt vocabulary from the English language, since the number of new names was so great that the creation of neologisms was not relevant. Currently, due to the global spread of media and the Internet, the number of borrowings in the Turkish language has increased unusually. Using linguistic and cultural procedures and taking into account the peculiarities of cultural and historical evolution, the Turkish language reveals the national identities of a nation by means of language, preserving and transmitting the value connotations of the cultural code.

Key words: culture, Black Sea region, Turkey, Turkic languages, West European borrowings.

\section{[Ю.А. Петрова, К.А. Кулешова Культурно-историческая эволюция турецкого языка под влиянием и заимствованием европейских языков]}

Рассматривается вопрос, актуальный для турецкой лингвистики, - вопрос заимствования слов из различных европейских языков. Турецкий язык - это язык, относящийся к тюркской группе языков. Долгое время турецкий алфавит складывался из букв арабского письма, пока те не были заменены на латинские. В настоящее время национальный турецкий язык представляет собой синтез народного языка Турции, старотюркского языка и азиатских тюркских языков. Турецкий язык также содержит множество заимствований, пришедших из словарного запаса других стран. Отмечается, что большое количество заимствований в турецком языке составляют заимствования из французского языка, которые проникали в лексику турок через включение французской литературы в образовательную программу школ. С того времени важным критерием образованности человека являлось умение говорить на иностранном языке. Возрастание значимости Турции в сфере торговли и мореплавания привело к появлению множества морских терминов, заимствованных из итальянского языка. Лозаннский договор, на основании которого происходил обмен населенными пунктами между Турцией и Грецией, является причиной существующих в турецком словарном запасе греческих заимствований феодальной терминологии и бытовой лексики. Подчеркивается, что источником английских заимствований служит научно-технический прогресс, терминологический взрыв которого вынуждал перенимать лексику из английского языка, поскольку число новых наименований было так велико, что создание неологизмов не являлось актуальным. В настоящее время глобального распространения средств массовой информации, интернета количество заимствований в турецком языке необычайно возросло. С помощью лингвокультурологических процедур и с учетом особенностей культурно-исторической эволюции турецкий язык раскрывает национальные идентичности нации по средствам языка, сохраняя и передавая ценностные коннотации культурного кода.

Ключевые слова: культура, Причерноморье, Турция, тюркские языки, западноевропейские заимствования. 
Yulia A. Petrova - Ph.D. in Philosophy, Associate Professor, Rostov State University of Economics, Rostov-onDon, Russian Federation.

Ksenia A. Kuleshova - student, Rostov State University of Economics, Rostov-on-Don, Russian Federation.

Петрова Юлия Андреевна - кандидат фрилософрских наук, доцент, Ростовский государственный экономический университет, е. Ростов-на-Дону, Российская Федерация.

Кулешова Ксения Алексеевна - студентка, Ростовский государственный экономический универсиmет, г. Ростов-на-Дону, Российская Федерация.

The national language of Turkey is the Turkish language, which belongs to the Turkic group of languages. For a long time, the Turkish alphabet consisted of the letters of Persian and Arabic letters, however, in 1928 Mustafa Kemal Atatürk, a Turkish state and political figure, set out to improve the language of Turkey, as a result of which the Latin letters served as a substitute for Arabic. In modern conditions, the Turkish language can be said to be a combination of the Turkish folk language, Old Turkic and Asian Turkic languages, and it contains many borrowings from the vocabulary of other countries. Initially, before the revolution of 1918-1923 and the declaration of Turkey as a Republic, the language was called Ottoman by the name of the Ottoman Empire. The replacement of borrowings with truly Turkic word stock took place already in the 1930s thanks to the language policy of the Turkish linguistic society. The Turkish language, in the process of its development and improvement, took in itself borrowings from languages such as French, Italian, Greek and English.

The end of the XVIII century is the period when the Turkish language began to replenish actively with borrowings from the French language. One of the reasons for this phenomenon was the creation of capital schools, classes in which were held exclusively in French. A considerable influence on the development of national literature and on the accumulation of borrowings was made by French literature, which was studied in educational institutions and was a source of inspiration for poets and writers of Turkey [2, pp. 49-65].

The work "Language Reform in Modern Turkey" is worth mentioning, which deals with the reform of the Turkish language in the mid-nineteenth century. Under the influence of European culture, the executive, legislative and educational systems were modernized, which caused significant changes in the Turkish language. The volume of borrowed words was replenished at an incredible rate due to the need for new names coming from European languages. The first words appeared that denoted new objects, after the word, which served as a replacement for the original Turkish vocabulary. It is believed that the Turkish linguistic society, originating in 1932, from time to time deliberately increased the number of European borrowings in the vocabulary of the Turkish language by replacing the Arabic-Persian lexicon with the western one, since during the process the so-called "Europeanization" Western terminology was considered a priority.

Compared with the process of adopting Arabic-Persian vocabulary, the adoption of European borrowings was more limited. The introduction of Latin letters, numerous translations of foreign literature, an increase in the level of knowledge in the study of Western languages by all sectors of the population - all this contributed to the emergence of the largest number of borrowings in the national language of Turkey. The process of their implementation intensified, it was becoming easier and easier.

It is worth noting that knowledge of the French language was an indicator of human education. Turkish linguistic society made unsuccessful attempts, if not to reduce the number of borrowings, then at least stop their growth. The members of this society made attempts to replace some of the borrowings with Turkish neologisms, but there were few successful analogues [9, p. 116]. Perceiving vocabulary, priority was given to French forms (deterjan, kilosikl). Speaking of the vowel sounds in Turkish (a, o, i, ö, ü), one can notice that they are very similar to similar French ones. Forming feminine nouns, the ready-made, pre- 
viously created forms of the French language (aktris, dansöz) are used in the Turkish language. There are frequent cases when French borrowings were combined with the Turkish words kız "girl" or kadın "woman" (kadın garson "waitress"). I would like to note that directly in French the word garçon refers to the masculine gender ("guy", "man"), but the inhabitants of Turkish lands, not understanding the meaning, interpreted it as a feminine word. If we talk about stresses, European borrowings often left their true stress on the penultimate syllable (lokanta, gazete) [11, p. 303].

Turkish language borrowed not only words, but also some grammar. For example, French syntactic combinations migrated into it, such as:

1) communication between words using the preposition de (tabldot, ropdöşambr);

2) a defining adjective does not stand before the noun, but after it (ekonomi politik, kartpostal, postrestant, şezlong) [12, p. 696].

The 1959 French Influence on the Turkish Language Study stated that in Turkish the French words in their written expression also corresponded to pronunciation. However, in Turkish, unlike French, the duration of vowels was not respected (ruj, hektar). To show softness in the pronunciation of the letter (I), the ${ }^{\wedge}$ symbol is used before the vowel (a). The consonant (n), used to create nasal vowels, began to be pronounced in Turkish (balkon, restoran). Speaking of stresses, it is worth noting that French vocabulary generally had no difficulties in switching to Turkish, but there are several cases when the French word was stressed on the penultimate syllable, imitating the Italian pattern (manto, parke). As for the semantic meaning, it is not uncommon for a borrowed word from a foreign language to take on a completely different meaning in Turkish, different from the original. For example, the French Dis donc means "Hey, you!", but the Turks pronounced this combination together, like didon, which originally had the meaning "French" and then "dude". The French word comtesse "countess" for schoolchildren, and then for the entire Turkish population, began to mean "teacher" - kontes. The flow of borrowings from the French language penetrated into such areas as science, art, sports and industry. The vocabulary, which is an integral part of the Turkish language and serves as the names for items of clothing, furniture and products, is diverse. At first glance, the number of borrowings from the French language can cause a sense of anxiety, but do not forget that "horizons of progress" were discovered with their help, and the Turkish language added new expressions to its vocabulary, which, undoubtedly, is an indispensable contribution to the culture of the country.

If we compare the statistics of dictionaries of different years of production, we can see that the number of borrowings from the French language is steadily growing every year; in the 1885 dictionary - 165 French borrowings, in the 1896 dictionary - 269, in the 1928 dictionary - 1412, in the 1939 dictionary - 1968, in the 1941 dictionary - 2411, in the 1945 dictionary - 2482 and, finally, in the 1955 dictionary - 2500. However, we must not miss the fact that the special vocabulary used by workers in the scientific, medical sphere, mechanics, creative figures, etc. for a number of unknown reasons, did not count. This is confirmed by the fact that there were much more French borrowings in the vocabulary of the Turkish language, and we can only guess how much [8, p. 31].

French borrowings have a significant percentage among all borrowings of the Turkish language, but do not forget about the contribution to the Italian vocabulary of Italian and Greek. From the study "Lingua franca in the Levant" in 1985, we determine that from the XV till the XVIII centuries in the Turkish language a lot of words appeared from the above languages, most of them were nautical terms. The work presents 723 Italian and 155 Greek borrowings. Particular attention is paid to the role of the Greek language in the transmission of Italian vocabulary [10, p. 752].

Italian words joined the Turkish lexicon due to the serious significance acquired by the Italian republics in the fifteenth century in the field of trade and shipping. The Ottoman Em- 
pire at that time took over from the Italian language the bulk of the financial, commercial and maritime names, which are used to this day.

It is generally accepted that there are two ways of the possible penetration of Greek borrowings into the vocabulary of Turkey:

1. The Turkish population studied some Greek institutions, at the same time adopting and terminology;

2. Directly through communication between the Turkish population and the Greek population, since the latter lived in such Turkish cities as Istanbul and Izmir until 1923-1925. The reason was the Lausanne Treaty of 1923 , on the basis of which the population was exchanged. However, Greek borrowings are not numerous, they include old feudal terms and typical household vocabulary [1, pp. 121-134].

The number of Greek and Italian borrowings combined will not compete with the number of French borrowings. The English language can, one of the main world languages, which to this day is a source of enrichment of the vocabulary of many countries [4, p. 238].

As the study of the historical interaction between English and Turkish shows, the latter until the early 1930s was not exposed to any influence from the English language. At present, neologisms play far from the last role in the vocabulary of the Turkish language. The Kemalist revolution, which fundamentally reversed the economy and life, created new interconnections, things, objects, goods, definitions, for the designation of which new lexical units were invented, the borrowing of which came mostly from the English language. The transition to the Latin script provided an even larger penetration of borrowings from the English language, as they began to be adopted in writing, which, in turn, was introduced through various translations of English texts.

It is well known that it is precisely in the process of translation a language borrows the greatest number of words. The Turkish language was no exception, adding to itself a large layer of English terminology, which can be attributed to different layers of the literary language of Turkey. Among international names, a large number of English names penetrate into many spheres of human knowledge. English has become, in a sense, a pioneer in the scientific and technological revolution and caused a terminological explosion. Researchers emphasize that the spread of English and international words is increasing every year for the development of the Turkish population, and at this time in the Turkish vocabulary in the field of scientific and socio-political names, the number of borrowings is more than the number of indigenous Turkish words [7]. It is important to note that the transfer of English terminology into Turkish vocabulary for almost a century has been without phonetic changes in words. There is nothing surprising in such a large number of borrowings of English names in the Turkish language.

Over the past decades, many important events have taken place in Turkey: a change in the political system and political situation, a reassessment of social and civic values, and openness to the West in orientation in the field of economy and politics. The involvement of a particular sphere of activity in international cooperation opens the vocabulary and names of this sphere to foreign innovations [5, pp. 142-161]. gories:

English borrowings make up numerous groups that can be classified into various cate-

1. Scientific and technical terminology. This category contains lexical units that form the terminology of the fields of science: acut - acute; stress - stress; çekap - check up; hekır hacker; hyperlink - hyperlink; çita - cheetah; flamingo - flamingo; greypfrut - grapefruit; caz - jazz; hit - hit;

2. Names, the reason for the formation of which is the economic development of Turkey and its language, respectively: accseptans - acceptance; banknot - banknote; çekcheck, cheque; aktüeryal - actuarial; partner - partner; 
3. Socio-political vocabulary: aparthayd (apartheaid) - racial isolation; boykot (boycott) - boycott, lider (leader) - leader, lort (lord) - lord, etc.

4. Sports names can be considered one of the largest groups of modern English borrowings: averaj - average; çelenç - challenge; rally - rally; jogging - jogging; sprint - sprint; hokey - hockey; ski - ski, basketbol - basketball; golf - golf; boks - box.

5. The vocabulary of show business: blucin - blue-jeans; blazer- blazer; bermuda bermudas, bermuda shorts; cin - gin; frak - frock; kep -cap; medya - mass media; show show; rating - rating [6, pp. 137-142].

Determining the reasons for filling the Turkish language with European borrowings, it can be assumed that the reason was the cessation of ties with the culture of the East and the establishment of ties with the culture of the West. Do not forget that many schools began to learn foreign languages, and many young people had the goal of getting an education in the West and, in order to achieve it, they studied Western languages. The number of contacts with Western countries in science, art, trade, etc. has also increased. All of these circumstances, to a greater or lesser extent, influenced the Turkish language in many areas. An important role was played by the craving of uneducated people for the educated ones, and they, trying to imitate, studied foreign languages. Borrowings from European vocabulary were found in journalism (anons, politik) and sports articles (ekip, maç, tribün). In shops, ateliers, hairdressers, European names of clothes, jewelry, and toiletries were used (fason, kostüm, model). The scientific worker and people of art used foreign names (aktör, artist, filolog). The scientific and technical process, which did not bypass Turkey, required Turkish analogues for a huge flow of Western lexical units. However, their number was so numerous, and penetration into everyday life is so inevitable that making efforts in the search for analogues was useless. For this reason, a large number of borrowings have successfully taken root in the Turkish language (traktör, astronot, radar). Drivers of vehicles used the names: pedal, vites, etc. A number of Western borrowings used in state institutions, in instructions, official letters, became widespread in the language of the whole people (dekan, kontrolör, üniversite).

Comparing data on the lexical composition of the Turkish language before and after alphabetical reform, we can observe such changes: the 1901 dictionary gives us information about 1,133 borrowings, and the 1974 dictionary gives us information about 4,266 borrowings in the Turkish language. Thus, the volume of European vocabulary increased by $10.2 \%$, and the number of Persian-Arabic words decreased by more than 30\% [3, pp. 170-174].

\section{Лumepamypa}

1. Баскаков Н. А. К вопросу о классификации тюркских языков // Известия АН СССР. Отделение литературы и языка. Вып. 2. 1952. №.11. С. 121-134

2. Брейтер М. А. Процесс языкового заимствования как способ реализации коммуникативных потребностей в рамках межкультурного взаимодействия, Лингвокогнитивные проблемы коммуникации. М., 1997. С. 49-65.

3. Буров А.Г. Лингвисты дальнего зарубежья о западноевропейских заимствованиях в турецком языке, Культура народов Причерноморья. № 39. Симферополь: Межвузовский центр «Крым». 2003. С. 170-174.

4. Журавлев, В.К. Современная идеологическая борьба и проблемы языка. М: Наука, 1984. C. 238.

5. Крысин, Л.П. Иноязычное слово в контексте современной общественной жизни. Русский язык конца XIX столетия (1985-1995гг.). М: Языки русской культуры, 2000. С. 142-161. 
6. Мамедова Н. Я. Обогащение словарного состава турецкого литературного языка английскими заимствованиями, Ученые записки Таврического национального университета им. В.И. Вернадского Т. 22 (61). 2009. № 3. С. 137-142.

7. Banguoğlu, T. Türkçenin Grameri, T. Banguoğlu. İstanbul, 1974.

8. Esenkova E. Türk dilinde Fransız tesiri. İstanbul: Matbaacılık A.Ş. 1959. C. 31.

9. Heyd U. Language reform in modern Turkey. Jerusalem: Israel Oriental society. 1954. C. 116.

10. Kahane $H . \&$ R., Tietze $A$. The lingua franca in the Levant. Turkish nautical terms of Italian and Greek origin. Urbana: University of Illinois press, 1958. C. 752.

11. Lewis G.L. Turkish grammar. Oxford: Clarendon press, 1967. P. 303.

12. Steuerwald K. Untersuchungen zur türkischen Sprache der Gegenwart, Langenscheidt, 1963. P. 696.

\section{References}

1. Baskakov N. A. K voprosu o klassifikatsii tyurkskikh yazykov. Izvestiya AN SSSR. Otdeleniye literatury i yazyka. [On the classification of Turkic languages. Bulletin of the USSR Academy of Sciences. Department of literature and language]. V. 2. 1952. No. 11. pp. 121134 (In Russian).

2. Breyter M. A. Protsess yazykovogo zaimstvovaniya kak sposob realizatsii kommunikativnykh potrebnostey $\mathrm{v}$ ramkakh mezhkulturnogo vzaimodeystviya. Lingvokognitivnyye problemy kommunikatsii. [The process of language borrowing as a way of realizing communicative needs within the framework of intercultural interaction. Linguocognitive problems of communication]. Moscow. 1997. pp. 49-65 (In Russian).

3. Burov A.G. Lingvisty dalnego zarubezhya o zapadnoyevropeyskikh zaimstvovaniyakh v turetskom yazyke. Kultura narodov Prichernomorya. [Foreign linguists on Western European borrowings in the Turkish language, Culture of the Black Sea peoples]. No. 39. Simferopol: Mezhvuzovskiy tsentr «Krym». 2003. pp. 170-17. (In Russian).

4. Zhuravlev V.K. Sovremennaya ideologicheskaya borba i problemy yazyka. [Modern ideological struggle and language problems]. Moscow: Nauka. 1984. 238 p. (In Russian).

5. Krysin L.P. Inoyazychnoye slovo $v$ kontekste sovremennoy obshchestvennoy zhizni. Russkiy yazyk kontsa XIX stoletiya (1985-1995 gg.). [A foreign language word in the context of modern public life. Russian language of the end of the XIX century (1985-1995)]. Moscow: Yazyki russkoy kultury, 2000. pp. 142-161 (In Russian).

6. Mamedova N.Ya. Obogashcheniye slovarnogo sostava turetskogo literaturnogo yazyka angliyskimi zaimstvovaniyami, Uchenyye zapiski Tavricheskogo natsional'nogo uni-versiteta im. V.I. Vernadskogo». [Enrichment of the vocabulary of the Turkish literary language with English borrowings, scientific notes of Taurida National University named after V.I. Vernadsky]. V. 22 (61). No. 3. 2009. pp. 137-142 (In Russian).

7. Banguoğlu, T. Türkçenin Grameri, T. Banguoğlu. İstanbul, 1974.

8. Esenkova E. Türk dilinde Fransız tesiri. İstanbul: Matbaacılık A.Ş. 1959. 31 p.

9. Heyd U. Language reform in modern Turkey. Jerusalem: Israel Oriental society. 1954. 116 p.

10. Kahane $H . \& R$., Tietze A. The lingua franca in the Levant. Turkish nautical terms of Italian and Greek origin. Urbana: University of Illinois press, 1958. 752 p.

11. Lewis G.L. Turkish grammar. Oxford: Clarendon press, 1967. 303 p.

12. Steuerwald K. Untersuchungen zur türkischen Sprache der Gegenwart, Langenscheidt, 1963. $696 \mathrm{p}$. 